\title{
POTENTIAL EFFECTS OF SOME NATURAL DIETARY SUPPLEMENTS ON ANTHROPOMETRIC CHARACTERISTICS AMONGST WEIGHTLIFTER ATHLETES
}

\author{
Hanem M. Gharib ${ }^{{ }^{\star}}$, Khallaf ${ }^{1}$ M.F., Abd El-Daim ${ }^{1}$ Y.A., \\ Ashoush $^{1}$ I.S. and Hammad ${ }^{2}$ E.M.
}

1- Food Sci. Dept., Fac. of Agric., Ain Shams Univ., P.O. Box 68, Hadayek Shobra 11241, Cairo, Egypt

2- National Institute of Nutrition, Cairo, Egypt

*Corresponding author:hanemma4983@gmail.com

Received 16 June, 2018

Accepted 11 July, 2018

\section{ABSTRACT}

This work was carried out to study the effect of using some natural dietary supplements; i.e. powders of date palm pits and pollen, ginseng roots, moringa leaves and royal jelly which giving orally in capsule to improve endurance of weightlifter athletes throughout 12 weeks in camp of sport Championship Sector belongs to the Armed Forces, Ministry of Defense, Future City, Cairo, Egypt. Collecting data showed that the suggested dietary supplement capsule had the highest value of the antioxidant activity (96.3\%) and significant increases in total phenolic and flavonoids content $(52.42 \& 63.1$ $\mathrm{mg} / \mathrm{g}$, respectively). Also, the anthropometric measurements showed a significant increase in weight and height in males compared to females. likewise, waist and mid upper arm circumference had significant increases in males compared to females, Male weightlifter athletes had significant muscles mass bigger than female one, and the fat mass for male was assessed as "Fitness" which ranged between (14 and 17\%) but the female had fat mass that assessed as "Athletes" which ranged between (14 and 20\%). The weights lifting by male and female increased during three months, and also revealed a significant increase in the efficiency of males in lifting weights higher than in the females during the period of 12 weeks. Thus, the results indicated that by incorporating natural dietary supplement powders in suggesting capsule, it is possible to enhance the performance of weightlifter athletes.
Keywords: Date palm pits and pollen, Ginseng roots, Moringa leaves, Royal jelly, Dietary supplement, Weightlifter athletes, Anthropometric measurements.

\section{INTRODUCTION}

Athletes consume dietary supplements in belief that they will boost their performance and modify their body composition. Dietary supplements are often highly marketed for their capability to growing muscle size and their force (Burns et al 2004; Herbold et al 2004; Yusko et al 2008).

Nutraceuticals, often referred as phytonutrients or functional foods, are natural bioactive chemical compounds that supply physiological benefits, beside their fundamental nutritional function. Although the use of nutraceuticals by athletes has a long history, but scientifically supported nutritional and medical evidence has allowed used nutraceuticals for their potentially effective. Many plants are perfect sources of antioxidants and act as immunomodulator. In recent years, plants and its products have been the main focus in the search for the nutraceuticals to fighting oxidative stress and enhance athlete's performance (Dillard and German 2000).

Date-pits (seeds) have an excellent nutritional quality because their elevation amounts of fiber and great amounts of minerals, vitamins, lipids and protein. Additionally, dates seeds were shown to be rich in antioxidants especially phenolics and total flavonoids (Soong and Barlow 2004; 
Al Farsi and Lee 2008; Habib and Ibrahim 2009; Habib et al 2013).

The date palm pollen of Phoenix dactylifera were used in conventional medicine for the treatment of various disorders which include memory disturbances, inflammation, fever, paralysis, loss of consciousness and numerous nervous disorders (Biglari et al 2008). The high concentrations of total phenolic content, flavonoids and anthocyanins as well as the presence of considerable quantities of selenoproteins in date palm pollen makes it an excellent source for processes of antioxidant (Baliga et al 2011).

Ginseng roots (Panax ginseng) have been used as conventional medicine and functional food. The health beneficial aspects of ginseng are well known as common tonics, which ameliorate health functions such as wound healing, rising stamina and immunomodulator. The advantageous function of ginseng is mainly depending on the bioactive components such as saponins, free amino acids and polyphenol (Yun et al 2001; Chang et al 2003).

The Moringa leaves (Moringa oleifera) are reported to be a good sources of phytonutrients such as vitamins $A, C$ and $E$, proteins, calcium, potassium, magnesium, iron, manganese, copper, also they contain appreciable amounts of total phenols and carotenoids (DanMalam et al 2001; Saini et al 2014a, 2014b and Hekmat et al 2015).

Royal jelly is known as a conventional food for health promotion. It is a viscous substance secreted by worker honeybees. Royal jelly contains great amounts of proteins, free amino acids, lipids, vitamins and sugars, and is known to have several physiological and pharmacological functions in humans. Which include immunomodulator, antihypercholesterolemic and antitumor activities (Mateescu and Barbulescu 1999).

The goal of this research was to determine the phytochemical activity of five potential natural dietary supplements on high performance endurance athletes like weightlifters and their anthropometric characteristics.

\section{MATERIALS AND METHODS}

\section{Materials}

Five natural dietary supplement powders obtained from Harraz Planta Medical Group, Cairo, Egypt, of (date palm pits and pollen, ginseng, moringa leaves and royal jelly) were. While, sodium carbonate and methanol were obtained from
El-Gomhoreya Co., Cairo, Egypt. 2,2-diphenyl-2picrylhydrazyl radical (DPPH) and Folin-Ciocalteus phenol reagent were purchased from SigmaAldrich Inc. (St Louis, MO, USA).

\section{Preparation of the dietary supplement capsule}

The five natural dietary supplement powders were mixed to prepare the suggested capsule at the following percentages: $30 \%$ date- pits: $20 \%$ date palm pollen: $20 \%$ ginseng roots: $20 \%$ moringa leaves: $10 \%$ royal jelly. Half gram of the mixture was taken and prepared in gelatin capsule for taking orally by weightlifter athletes.

\section{Proximate analyses of dietary supplement ma- terials}

The five natural dietary supplement powders were analyzed for their moisture content, ash, crude fiber, protein and fat contents, according to the methods described in AOAC (2007). The energy value was calculated based on their content of crude protein, fat and carbohydrate using formula described by Crisan and Sands (1978) as follows: Energy value $(\mathrm{kcal} / 100 \mathrm{gm})=(2.62 \times \%$ protein $)+(8.37 \times \%$ fat $)+(4.2 \times \%$ carbohydrate $)$.

\section{Samples extraction}

Each of the five natural dietary supplement powders were extracted with methanol $(70 \%)$ with shaking the mixture for one hour then filtered with Whatman No.1 filter paper as described by Bloor (2001). The extracts were labeled and kept for laboratory analysis.

\section{Determination of total phenolic content}

The total phenolic content of the extracts was calorimetrically determined, using the FolinCiocalteu method, described by Singleton et al (1999). Aliquots of $0.5 \mathrm{ml}$ of each extract were added to $0.5 \mathrm{ml}$ of folin reagent, followed by adding $0.5 \mathrm{ml}$ of an aqueous $7.5 \%$ solution of sodium carbonate. The mixture was stirred and allowed to stand for $30 \mathrm{~min}$. The absorbance at $765 \mathrm{~nm}$, blank sample consisting of water and reagents was used as a reference. The results were expressed as milligram of gallic acid equivalent per $\mathrm{ml}$ extract (mg GAE/ml) by reference to the gallic acid calibration curve. 


\section{Total flavonoids content (TFC) assay}

The total flavonoids content was determined according to the method of Mohdaly et al (2012). A $100 \mu \mathrm{L}$ aliquot of $2 \% \mathrm{AICl}_{3}$ ethanolic solution was added to $100 \mu \mathrm{L}$ of the extract and mixed well. After keeping for $1 \mathrm{~h}$ at room temperature, the absorbance at $420 \mathrm{~nm}$ was measured. A yellow color indicates the presence of flavonoids. The total flavonoid contents were expressed as milligram quercetin equivalents $(\mathrm{QE})$.

\section{DPPH-radical scavenging activity (\%)}

The ability of the extracts to scavenge DPPH free radicals was determined according to (BrandWilliams et al 1995). Aliquots $0.1 \mathrm{ml}$ of sample extract was mixed with $2.9 \mathrm{ml}$ of $0.1 \mathrm{mM} \mathrm{DPPH}$ in methanol. The control samples contained all the reagents except the extract. The reaction mixture was shaken well and allowed to react for $20 \mathrm{~min}$ at room temperature. The remaining DPPH free radical was determined by absorbance measurement at $517 \mathrm{~nm}$ against methanol blank. The percentage scavenging effect was calculated from the decreased absorbance against control according to the following equation:

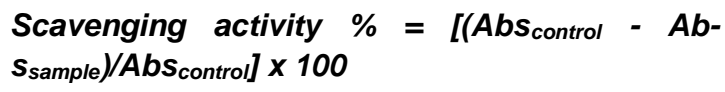

\section{Study design and subjects}

The study was conducted on 5 male and 5 female weightlifter athletes aged 16 - 25 years, trained in Athletic Championship Sector belongs to Army Forces, Ministry of Defense, Future City; Cairo, Egypt. The given dose was 1-2 of suggested dietary supplement capsule daily according to the player's body weight: Less than $70 \mathrm{~kg}$ body weight take one capsule before morning training (7:30 am) and one capsule before evening training (4:00 pm). More than $70 \mathrm{~kg}$ body weight take two capsules before morning training (7:30 am) and two capsules before evening training $(4: 00 \mathrm{pm})$ for 12 weeks.

This study was approved by the Committee of Ethics for Athletic Championship Sector belongs to Army Forces, Ministry of Defense, Future City; Cairo, Egypt.

\section{Anthropometric measures}

Anthropometric measurements included body weight and height; waist and mid upper arm circumferences; and calculated waist-to-height ratio. Waist and mid upper arm circumferences were measured by anthropometric tape. Body mass index (BMI) and ideal body weight percentage (IBW \%) were also calculated. All measurements were performed according to the techniques described by WHO (2008); Lee et al (2008); Whitney et al (2010), respectively.

\section{Determination of body composition}

Body composition was determined from skinfold measurement. Skinfolds were measured in $\mathrm{mm}$ at four sites of the body: triceps, thigh, suprailiac and at abdomen region using Lange Skinfold Caliper with constant tension. Different components of body composition were assessed by using standardized equations according to (Jackson \& Pollock 1978; Jackson et al 1980).

\section{Physical performance parameters}

The six recommended parameters that used for evaluating the performance of weightlifting players are known as: front squat; back squat; power snatch; snatch; power clean \& jerk as well as clean $\&$ jerk were evaluated and recorded as a progressive weightlifts for each player every two weeks, the beginning of the evaluation was after four weeks of taking the suggested dietary supplement capsule.

\section{Statistical analysis}

Descriptive values of data were represented as means \pm standard errors. Statistical analysis was performed using one way analysis of variance (ANOVA) followed by Duncan's multiple range test with $P \leq 0.05$ being considered statistically significant (Steel et al 1997). Statistical analysis was conducted with SAS program (SAS 2008). 


\section{RESULTS AND DISCUSSION}

Proximate composition of dietary supplement materials

Data given in Table (1) indicated that the datepits powder had the highest caloric value compared with the other substances. While, royal jelly recorded the highest protein and fat content, moringa leaves showed high content of ash and fiber. Date palm pollen recorded the highest carbohydrate and moisture contents. This observation is agreed with those reported by (Mateescu and Barbulescu 1999; Chang et al 2003; Baliga et al 2011; Habib et al 2013; Hekmat et al 2015).

Table 1. Proximate composition \% of dietary supplement materials

\begin{tabular}{|c|c|c|c|c|c|}
\hline \multirow{2}{*}{ Analysis } & \multicolumn{5}{|c|}{ Dietary supplement } \\
\cline { 2 - 6 } & Date- pits & Date pollen & Ginseng roots & Moringa leaves & Royal jelly \\
\hline Moisture & $9.49 \pm 0.03^{\mathrm{b}}$ & $11.48 \pm 0.01^{\mathrm{a}}$ & $4.11 \pm 0.01^{\mathrm{e}}$ & $5.2 \pm 0.06^{\mathrm{d}}$ & $6.09 \pm 0.02^{\mathrm{c}}$ \\
Ash & $1.21 \pm 0.01^{\mathrm{d}}$ & $0.46 \pm 0.01^{\mathrm{e}}$ & $4.82 \pm 0.01^{\mathrm{b}}$ & $8.35 \pm 0.01^{\mathrm{a}}$ & $3.76 \pm 0.01^{\mathrm{c}}$ \\
Fat & $8.20 \pm 0.01^{\mathrm{b}}$ & $1.15 \pm 0.01^{\mathrm{d}}$ & $0.87 \pm 0.01^{\mathrm{e}}$ & $5.73 \pm 0.01^{\mathrm{c}}$ & $8.30 \pm 0.01^{\mathrm{a}}$ \\
Protein & $5.78 \pm 0.01^{\mathrm{d}}$ & $1.08 \pm 0.01 \mathrm{e}$ & $13.75 \pm 0.01^{\mathrm{c}}$ & $28.51 \pm 0.01^{\mathrm{b}}$ & $30.43 \pm 0.04^{\mathrm{a}}$ \\
Fiber & $1.50 \pm 0.01^{\mathrm{b}}$ & $0.18 \pm 0.01^{\mathrm{c}}$ & $0.09 \pm 0.01^{\mathrm{d}}$ & $19.15 \pm 0.05^{\mathrm{a}}$ & $\mathrm{ND}$ \\
Carbohydrate & $73.82 \pm 0.03^{\mathrm{c}}$ & $85.64 \pm 0.01^{\mathrm{a}}$ & $76.40 \pm 0.02^{\mathrm{b}}$ & $33.07 \pm 0.07^{\mathrm{e}}$ & $51.42 \pm 0.03^{\mathrm{d}}$ \\
Caloric Kcal/100g & $393.81 \pm 0.08^{\mathrm{a}}$ & $372.16 \pm 0.01^{\mathrm{b}}$ & $364.09 \pm 0.03^{\mathrm{d}}$ & $261.53 \pm 0.33^{\mathrm{e}}$ & $365.21 \pm 0.05^{\mathrm{c}}$ \\
\hline
\end{tabular}

$\mathrm{N}=3$, means in the same raw with the same letter are not significantly different $(P<0.05)$.

ND: Not detect

Antioxidant status of dietary supplement materials

The results of the antioxidant status assessment in Table (2) showed that the suggested dietary supplement capsule had the highest value of the antioxidant activity (96.3\%), followed respectively by date-pits $>$ palm heart $>$ royal jelly $>$ ginseng roots $>$ moringa leaves.
A significant increase was noticed in the content of phenols and total flavonoids of the proposed dietary supplement capsule $(52.42,63.1 \mathrm{mg} / \mathrm{g}$, respectively). While, for the dietary supplement materials, the moringa leaves showed the highest phenols content $(45.83 \mathrm{mg} / \mathrm{ml})$. Meanwhile, the royal jelly recorded the highest content of total flavonoids $(42.13 \mathrm{mg} / \mathrm{g}$ ) compared to other raw materials. These findings are in harmony with those obtained by DanMalam et al (2001); Yun et al (2001); Al Farsi and Lee (2008).

Table 2. Antioxidant status of dietary supplement materials

\begin{tabular}{|c|c|c|c|}
\hline \multirow[b]{2}{*}{ Dietary supplement } & \multicolumn{3}{|c|}{ Antioxidant status } \\
\hline & $\begin{array}{l}\text { Total phenols } \\
\qquad(\mathrm{mg} / \mathrm{g}) \\
\text { as gallic acid }\end{array}$ & $\begin{array}{c}\text { Total flavonoids } \\
(\mathbf{m g} / \mathbf{g}) \\
\text { as quercetin } \\
\end{array}$ & $\begin{array}{c}\text { Scavenging activity } \\
\%\end{array}$ \\
\hline Date- pits & $27.54 \pm 1.21^{d}$ & $4.65 \pm 0.02^{\dagger}$ & $76.21 \pm 1.11^{b}$ \\
\hline Palm pollen & $35.81 \pm 0.01^{\mathrm{c}}$ & $11.72 \pm 0.02^{\mathrm{e}}$ & $68.55 \pm 0.11^{\mathrm{c}}$ \\
\hline Ginseng roots & $3.82 \pm 0.02^{f}$ & $29.92 \pm 0.02^{c}$ & $47.54 \pm 0.83^{\mathrm{e}}$ \\
\hline Moringa leaves & $45.83 \pm 1.14^{b}$ & $27.04 \pm 0.11^{d}$ & $18.31 \pm 0.32^{f}$ \\
\hline Royal jelly & $22.82 \pm 0.13^{\mathrm{e}}$ & $42.13 \pm 0.08^{b}$ & $58.52 \pm 1.71^{d}$ \\
\hline Suggested capsule & $52.42 \pm 0.13^{\mathrm{a}}$ & $63.10 \pm 0.09^{\mathrm{a}}$ & $96.30 \pm 0.56^{\mathrm{a}}$ \\
\hline
\end{tabular}

$\mathrm{N}=3$, means in the same column with the same letter are not significantly different $(\mathrm{P}<0.05)$. 

characteristics amongst weightlifter athletes

The anthropometric characteristics for weightlifter athletes

Data observed in Table (3) indicated that the anthropometric measurements showed a significant increase in weight and height in males compared to females, but not significant differences within the body mass index and ideal weight and did not reach the level of obesity. Also, the results of the waist and mid upper arm circumference had significant increase in males compared to females. These results are in parallel with those of (Ioná et al 2007) reported that the male adventure racers presented significantly higher values than did female athletes.

Table 3. The anthropometric characteristics for weightlifter athletes

\begin{tabular}{|l|c|c|}
\hline \multirow{2}{*}{ Variable } & \multicolumn{2}{c|}{ weightlifting athletes } \\
\cline { 2 - 3 } & Male & Female \\
\hline Weight, kg & $79.40 \pm 4.03^{\mathrm{a}}$ & $65.40 \pm 4.01^{\mathrm{b}}$ \\
Height, cm & $174.0 \pm 2.54^{\mathrm{a}}$ & $165.0 \pm 3.19^{\mathrm{b}}$ \\
BMI, kg/m ${ }^{2}$ & $26.11 \pm 1.40^{\mathrm{a}}$ & $24.03 \pm 1.36^{\mathrm{a}}$ \\
IBW, \% & $112.31 \pm 5.32^{\mathrm{a}}$ & $97.02 \pm 6.44^{\mathrm{a}}$ \\
Waist circumference, cm & $33.71 \pm 0.21^{\mathrm{a}}$ & $31.50 \pm 0.71^{\mathrm{b}}$ \\
Waist-to-height ratio (WHtR), cm & $0.19 \pm 0.003^{\mathrm{a}}$ & $0.19 \pm 0.01^{\mathrm{a}}$ \\
Mid uper arm circumference index (MUAC), cm & $8.2 \pm 3.37^{\mathrm{a}}$ & $7.1 \pm 0.85^{\mathrm{b}}$ \\
\hline
\end{tabular}

$\mathrm{N}=5$, means in the same raw with the same letter are not significantly different $(\mathrm{P}<0.05)$.

Skinfolds and body composition of weightlifting athletes

The skin folds $(\mathrm{mm})$ at four sites and also the body composition of the male and female weightlifter athletes are given in Table (4). The skin folds at triceps, thigh, suprailiac and abdomen showed no significant tendency across the gender. While, body composition indicators showed that the athletes fell within normal limits. Male weightlifter athletes had significant muscles mass bigger than female, and the fat mass in male was assessed as "Fitness" which ranged between (14 and 17\%) but the female had fat mass was assessed as "Athletes" which ranged between (14 and 20\%). While, in another study by (Marius et al 2015) reported that all female endurance athletes among different sports like rowers, highway cyclists, swimmers, skiers, biathletes and long-distance runners, the fat mass was assessed as "optimal" which ranged between (20 and 24\%).

Effect of dietary supplement given in suggested capsule on physical performance parameters for weightlifter athletes

Data given in Table (5) indicated that, on studying the effect of dietary supplements capsule on the physical performance of weightlifters it was found through a series of exercises the ability of players to increase their weight which raised over 12 weeks from the weights recorded at intervals $(0$, $4,6,8,10$ and 12 weeks). The weights lifting by male and female increased during the previous periods, and also revealed a significant increase in the efficiency of males in lifting weights being higher than in the females during the period of experiment. 
Table 4. Skinfolds and body composition of weightlifting athletes

\begin{tabular}{|l|c|c|}
\hline \multirow{2}{*}{\multicolumn{1}{|c|}{ Variable }} & \multicolumn{2}{c|}{ weightlifting athletes } \\
\cline { 2 - 3 } & Male & \multicolumn{1}{c|}{ Female } \\
\hline Triceps skinfold thickness, $\mathbf{m m}$ & $18.80 \pm 4.91^{\mathrm{a}}$ & $13.20 \pm 0.86^{\mathrm{a}}$ \\
Thigh skinfold thickness, mm & $15.00 \pm 0.71^{\mathrm{a}}$ & $18.00 \pm 2.21^{\mathrm{a}}$ \\
Suprailiac skinfold thickness, $\mathbf{m m}$ & $15.40 \pm 3.91^{\mathrm{a}}$ & $13.20 \pm 2.39^{\mathrm{a}}$ \\
Abdomen skinfold thickness, $\mathbf{m m}$ & $24.80 \pm 2.69^{\mathrm{a}}$ & $22.40 \pm 1.28^{\mathrm{a}}$ \\
Body fat, \% & $16.00 \pm 2.02^{\mathrm{a}}$ & $20.00 \pm 1.38^{\mathrm{a}}$ \\
Fat mass, kg & $13.00 \pm 2.35^{\mathrm{a}}$ & $12.80 \pm 0.37^{\mathrm{a}}$ \\
Lean mass, kg & $66.40 \pm 2.38^{\mathrm{a}}$ & $52.60 \pm 4.06^{\mathrm{b}}$ \\
Body fat percentage category & Fitness $(14-17 \%)$ & Athletes $(14-20 \%)$ \\
\hline
\end{tabular}

$\mathrm{N}=5$, means in the same raw with the same letter are not significantly different $(\mathrm{P}<0.05)$.

Table 5. Effect of dietary supplement given in capsule on physical performance parameters for weightlifter athletes

\begin{tabular}{|c|c|c|c|c|c|c|}
\hline \multirow{2}{*}{ Parameters } & \multicolumn{6}{|c|}{ Period of evaluation (week) } \\
\hline & 0 & 4 & 6 & 8 & 10 & 12 \\
\hline \multicolumn{7}{|c|}{ Front squat, kg } \\
\hline Male & $157.4 a$ & $163.4 \mathrm{a}$ & $167.0 \mathrm{a}$ & $168.8 a$ & $169.0 \mathrm{a}$ & $170.8 \mathrm{a}$ \\
\hline Female & $95.8 b$ & $99.8 b$ & $102.4 b$ & $105.2 b$ & $107.4 b$ & $108.6 b$ \\
\hline \multicolumn{7}{|c|}{ Back squat, kg } \\
\hline Male & $178.0 \mathrm{a}$ & $185.4 a$ & $188.8 \mathrm{a}$ & $192.6 a$ & $195.4 \mathrm{a}$ & $195.0 \mathrm{a}$ \\
\hline Female & $100.4 b$ & $113.8 b$ & $116.2 b$ & $118.2 b$ & $120.4 b$ & $123.4 b$ \\
\hline \multicolumn{7}{|c|}{ Power snatch, kg } \\
\hline Male & $102.4 a$ & $106.8 \mathrm{a}$ & $110.8 \mathrm{a}$ & $112.8 \mathrm{a}$ & $116.0 \mathrm{a}$ & $117.8 \mathrm{a}$ \\
\hline Female & $57.8 \mathrm{~b}$ & $60.4 \mathrm{~b}$ & $62.6 \mathrm{~b}$ & $65.2 b$ & $67.2 \mathrm{~b}$ & $68.0 \mathrm{~b}$ \\
\hline \multicolumn{7}{|l|}{ Snatch, kg } \\
\hline Male & $116.0 \mathrm{a}$ & $121.4 a$ & $123.2 a$ & $124.8 \mathrm{a}$ & $126.6 a$ & $127.8 \mathrm{a}$ \\
\hline Female & $66.4 b$ & $70.0 \mathrm{~b}$ & $71.6 b$ & $73.4 b$ & $75.0 \mathrm{~b}$ & $77.4 \mathrm{~b}$ \\
\hline \multicolumn{7}{|c|}{ Power clean and jerk, kg } \\
\hline Male & $129.0 \mathrm{a}$ & $134.0 \mathrm{a}$ & $136.0 \mathrm{a}$ & $137.2 a$ & $136.8 \mathrm{a}$ & $137.4 \mathrm{a}$ \\
\hline Female & $71.8 b$ & $76.2 b$ & $78.4 b$ & $82.0 \mathrm{~b}$ & $83.2 b$ & $84.6 \mathrm{~b}$ \\
\hline \multicolumn{7}{|c|}{ Clean and jerk, kg } \\
\hline Male & $144.2 \mathrm{a}$ & $149.0 \mathrm{a}$ & $150.0 a$ & $152.2 \mathrm{a}$ & $153.0 \mathrm{a}$ & $155.0 \mathrm{a}$ \\
\hline Female & $84.8 \mathrm{~b}$ & $88.2 b$ & $91.0 \mathrm{~b}$ & $92.8 \mathrm{~b}$ & $95.0 \mathrm{~b}$ & $98.0 \mathrm{~b}$ \\
\hline
\end{tabular}

$\mathrm{N}=5$, means in the same column with the same letter for each parameter are not significantly different $(\mathrm{P}<0.05)$.

\section{CONCLUSION}

Based on the aforementioned results, it could be concluded that the natural dietary supplementing powders incorporated in suggested capsule could be used as a potential source for nutraceutical ingredients to improve the performance and improve endurance for weightlifting athletes.

\section{ACKNOWLEDGMENT}

Thanks and great fullness will not be enough words to Brigadier Fathi, M. Zoraik, Chairman of New Farosince Company for Scientific Research \& Engineering Supplements and the councilor weightlifting athletic in Athletic Championship Sector belongs to Army Forces, Ministry of Defense, Future City, Cairo, Egypt; for his valuable supports. 

characteristics amongst weightlifter athletes

\section{REFERENCES}

Al-Farsi M.A. and Lee C.Y. 2008. Nutritional and functional properties of dates: A review. Crit. Rev. Food Sci., 48, 877-887.

AOAC 2007. Official Methods of Analysis, $18^{\text {th }}$ Ed. Association of Official Analytical chemists, Gaithersburg, MD, USA.

Baliga M.S., Baliga B.R.V., Kandathil S.M., Bhat H.P. and Vayalil P.K. 2011. A review of the chemistry and pharmacology of the date fruits (Phoenix dactylifera L.), Food Res. Int., 44, 1812-1822.

Biglari A., AlKarkhi F.M. and Azhar M.E. 2008. Antioxidant activity and phenolic content of various date palm (Phoenix dactylifera) fruits from Iran, Food Chem., 107(4), 1636-1641.

Bloor S. 2001. Overview of methods for analysis and identification of flavonoids, Methods in Enzymology, 335, 3-14.

Brand-Williams W., Cuvelier M.E. and Berset C. 1995. Use of a free radical method to evaluate antioxidant activity. LebensmittelWissenschaft und -Technologie (LWT), 28, 25-30.

Burns R.D., Schiller M.R., Merrick M.A. and Wolf K.N. 2004. Intercollegiate student athlete use of nutritional supplements and the role of athletic trainers and dietitians in nutrition counseling. J. Am. Diet Assoc., 104(2), 246-249.

Chang Y.S., Seo E.K., Gyllenhaal C. and Block K.I. 2003. Panax ginseng: a role in cancer therapy. Integrative Cancer Therapies, 2, 1333.

Crisan E.V. and Sands A. 1978. Nutritional Value. Academic Press, New York, USA, pp. 137168.

DanMalam H., Abubakar Z. and Katsayal U. 2001. Pharmacognosostic studies on the leaves of moringa oleifera. Nig. J. Nat. Prod. Med., 5, 45-49.

Dillard C.J. and German J.B. 2000. Phytochemicals: nutraceuticals and human health. J. of the Sci. of Food and Agric., 80, 1744-1756.

Habib H. and Ibrahim W. 2009. Nutritional quality evaluation of eighteen date pit varieties. Int. J. Food Sci. Nutr. 60, 99-111.

Habib H., Kamal H., Ibrahim W. and Al Dhaheri A.S. 2013. Carotenoids, fat soluble vitamins and fatty acid profiles of 18 varieties of date seed oil. Ind. Crops Prod. 42, 567-572.

Hekmat S., Morgan K., Soltani M. and Gough R. 2015. Sensory evaluation of locally-grown fruit purees and inulin fiber on probiotic yogurt in mwanza, Tanzania and the microbial analysis of probiotic yogurt fortified with Moringa oleifera. J. Health Popul. Nutr., 33, 60-67.

Herbold N.H., Visconti B.K., Frates S. and Bandini L. 2004.Traditional and nontraditional supplement use by collegiate female varsity athletes. Int. J. Sport Nutr. Exerc . Metab ., 14(5), 586-593.

Ioná Z., Heloisa V.G., Claudia R.J., Cibele A.C., Hanna K.M.A., Edwards B., Sérgio T. and Marco T.M. 2007. Nutritional status of adventure racers. Nutrition 23, 404-411

Jackson A.S. and Pollock M.L. 1978. Generalized equations for predicting body density of men. British J. of Nutrition, 40, 497-504.

Jackson A.S., Pollock M.L. and Ward A. 1980. Generalized equations for predicting body density of women. Medicine and Sci. in Sports and Exercise, 12, 175-182.

Lee C.M., Huxley R.R., Wildman R.P. and Woodward M. 2008. Indices of abdominal obesity are better discriminators of cardiovascular risk factors than BMI: a meta-analysis. J. Clin. Epidemiol., 61, 646-653.

Marius B., Rimantas S., Linas T., Kęstutis Ž., Genè Š., Edmundas Š., Vincentas R.G., Valerij D. and Jonas A. 2015. Nutritional habits among high-performance endurance athletes. Medicina, 51, 351-362.

Mateescu C. and Barbulescu D. 1999. Enhanced nutritive, functional and therapeutic action of combined bee products in complex food supplements. Roumanian Biotechnol. Lett., 4, 163-172.

Mohdaly A.A.A., Hassanien M.F.R., Mahmoud A., Sarhan M.A. and Smetanska I. 2012. Phenolics extracted from potato, sugar beet, and sesame processing by-products. Int. J. of Food Properties, 16, 1148-1168.

Saini R., Prashanth K.H., Shetty N. and Giridhar P. 2014a. Enhance carotenoids and tocopherol biosynthesis and expression of antioxidant related genes in Moringa oleifera Lam. leaves. Acta Physiol. Plant, 36, 2695-2704.

Saini R., Shetty N., Prakash M. and Giridhar P. 2014b. Effect of dehydration methods on retention of carotenoids, tocopherols, ascorbic acid and antioxidant activity in Moringa oleifera leaves and preparation of a RTE product. J. Food Sci. Technol. 51, 2176-2182.

SAS System 2008. Statistical Analysis System. Version 9.2. Cary, USA: SAS Institute Inc.

Singleton V.L., Orthofer R., and LamuelaRavento's R.M. 1999. Analysis of total phenols 
and other oxidation substrates and antioxidants by means of Folin-Ciocalteu reagent. Methods in Enzymology, 299, 152-178.

Soong Y. and Barlow P.J. 2004. Antioxidant activity and phenolic content of selected fruit seeds. Food Chem., 88, 411-417.

Steel R., Torrie J. and Dickey D. 1997 Principles and Procedures of Statistics: A Biometrical Approach. $3^{\text {rd }}$ Ed, McGraw-Hill, New York, USA.

Whitney E., Kelly D.L., Pinna K. and Rady R.S. 2010. Nutrition for health and health care. Cengage Learning, 4, 394-395.
WHO, 2008. BMI categories. http://www.euro.who.int/ nutrition.

Yun T.K., Lee Y.S., Lee Y.H., Kim S.I. and Yun H.Y. 2001. Anticarcinogenic effect of Panax ginseng C.A. Meyer and identification of active compounds. J. of Korean Medical Sci., 16, S6-S18.

Yusko D.A., Buckman J.F., White H.R. and Pandina R.J. 2008. Alcohol, tobacco, illicit drugs, and performance enhancers: a comparison of use by college student athletes and nonathletes. J. Am. Coll. Health., 57(3), 281-290. 
مجلة اتحاد الجامعات العربية للعلوم الزراعية ، جامعة عين شمس ، القاهرة

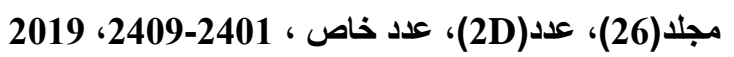

Website: http://strategy-plan.asu.edu.eg/AUJASCI/

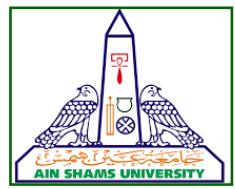

2409

\section{التأثرات المحتملة لبعض المكملات الغذائية الطبيعية على الخصائص الأنثرويومترية بين رياضيي رفع الأثقال}

[176]

$$
\begin{aligned}
& \text { هانم ممدوح غريب1 } 1 \text { - محد فرج خلاف1 - يسرى أحمد عبد الايم1 } 1 \text { - إيهاب صدلاح عشوش1 - } \\
& \text { السيد محمود حماد } 2 \\
& \text { 1- قسم علوم الأغذية - كلية الزراعة - جامعة عين شمس - ص.ب 68- } 11241 \text { حدائق شبرا - القاهرة - مصر } \\
& \text { 2- المعهد القومى للتغذية - القاهرة - مصر الرداعلة }
\end{aligned}
$$

*Corresponding author:hanemma4983@gmail.com

الذكور مقارنةً بالإناث، تبين في رياضات رفع الأثقال

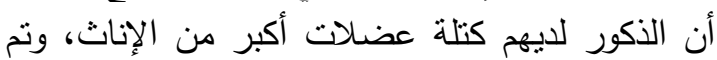

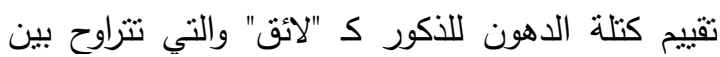
(14-14\%) لكن نم تقييم كتلة الدهون لدى الإناث

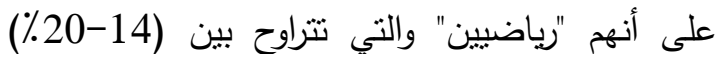
وزاد وزن الأثقال المرفوعة عند الذكور والإناث خلال

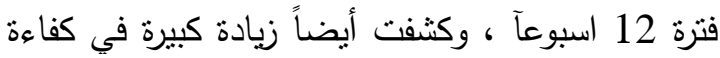

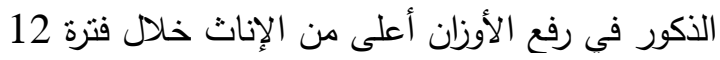

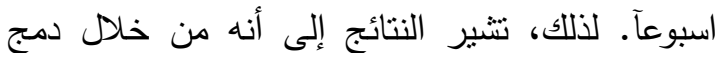

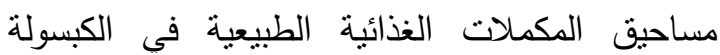

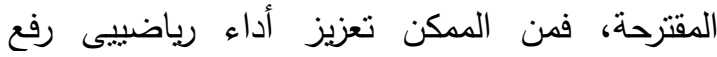

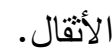

الكلمات الدالة: نوى البلح، طلع النذل، جذور

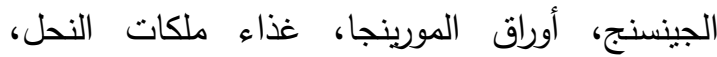

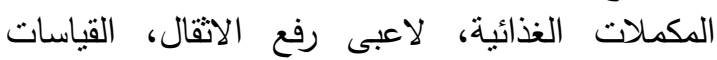
الأنثروبومترية الغنات<smiles>[AlH2][AlH2]</smiles>

تم تتفيذ هذا العمل لدراسة تأثير إستخدام بعض الطض

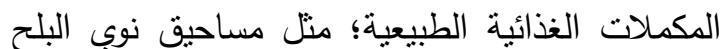

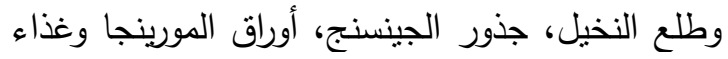
ملكات النحل التي تعطي عن طريق الفم في كبسولة

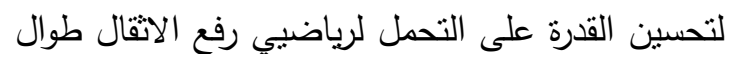

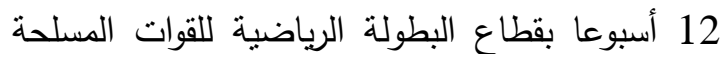

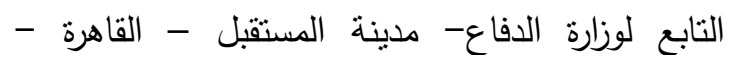

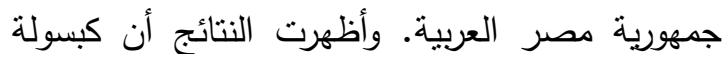

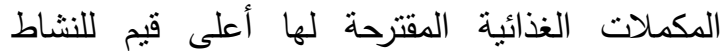

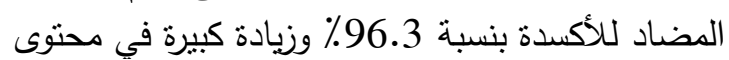
الفينولات والفلافونويد الكلية (52.42 و 63.1 ملجم/جرام على التوالي). أيضا أظهرت القياسات

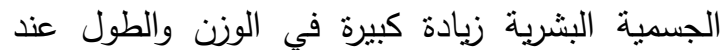
الذكور مقارنة بالإناث. وفي نقس الوقت كاند، كان محيط الجيط الخصر ومنتصف الجزء العلوي من الذراع بارزًا في الأي 
